\title{
Abundance and community structure of ammonia oxidizing bacteria and archaea in a Sweden boreal forest soil under 19-year fertilization and 12-year warming
}

\author{
Xien Long • Chengrong Chen • Zhihong Xu • \\ Sune Linder • Jizheng He
}

Received: 11 August 2011 / Accepted: 20 April 2012 /Published online: 3 May 2012

(C) Springer-Verlag 2012

\begin{abstract}
Purpose Boreal forests are considered to be more sensitive to global climate change compared with other terrestrial ecosystems, but the long-term impact of climate change and forest management on soil microbial functional diversity is not well understood. Ammonia-oxidizing bacteria (AOB) and archaea (AOA) are the most important players in nitrogen $(\mathrm{N})$ cycling-associated processes in terrestrial ecosystems. This study investigated the separate and combined impacts of long-term soil warming and fertilization on
\end{abstract}

Responsible editor: Yanfen Wang

$\mathrm{X}$. Long $\cdot \mathrm{J}$. He $(\bowtie)$

State Key Laboratory of Urban and Regional Ecology,

Research Centre for Eco-environmental Sciences,

Chinese Academy of Sciences,

Beijing 100085, People's Republic of China

e-mail: jzhe@rcees.ac.cn

X. Long

Graduate University, Chinese Academy of Sciences,

Beijing 100049, People's Republic of China

\section{$\mathrm{X}$. Long $\cdot \mathrm{Z}$. Xu}

Environmental Futures Centre and School of Biomolecular

and Physical Sciences, Griffith University,

Nathan,

Brisbane, QLD 4111, Australia

C. Chen $(\bowtie)$

Environmental Futures Centre and Griffith

School of Environment, Griffith University,

Nathan,

Brisbane, QLD 4111, Australia

e-mail: c.chen@griffith.edu.au

\section{S. Linder}

Southern Swedish Forest Research Centre,

Swedish University of Agricultural Sciences,

P.O. Box 49, SE-230 53 Alnarp, Sweden soil AOB and AOA community structures and abundances in a Norway spruce stand in northern Sweden.

Materials and methods The soil-warming experiment was established in the buffer zones of two irrigated plots $(I)$ and complete nutrient solution plots (IL) since 1995. The warming treatment started in April each year by maintaining soil temperature on warmed plots at $5^{\circ} \mathrm{C}$ above the temperature in unwarmed plots using heating cables. In August 2006, soil samples were collected from eight subplots for molecular analysis. The abundance of bacterial and archaeal amo $A$ genes was determined by quantitative polymerase chain reaction. Similarly, total bacterial and archaeal population sizes have also been determined. The diversity of AOB and AOA was assessed by constructing amoA gene clone libraries, and different genotypes were screened with restriction fragment length polymorphism.

Results and discussion Results showed that fertilization did not significantly affect the abundance of the bacterial amo $A$ gene under either warming or non-warming conditions; however, warming decreased the abundance under fertilization treatments. No significant effects of fertilization and soil warming were observed on the number of thaumarchaeal amo $A$ gene copies across all treatments. In this study, amo $A$ gene abundance of AOB was significantly higher than that of AOA across all treatments. The community structure of both AOB and AOA was strongly influenced by fertilization. For bacterial amoA genes, Nitrosospira cluster 2 was present across all treatments, but the only genotype was observed in the fertilization treatments while, for thaumarchaeal amo $A$ genes, the relative abundance of soil cluster 5 increased in fertilization treatments. By comparison, soil-warming effects on AOB and AOA community structure were not significant. Canonical correspondence analysis showed a positive correlation between fertilization and both dominant genotypes of $\mathrm{AOB}$ and AOA. 
Conclusions These results indicated that the abundance of $\mathrm{AOA}$ and $\mathrm{AOB}$ was not affected by fertilization or warming alone, but the interaction of fertilization and warming reduced the abundance of AOB. The community composition of ammonia-oxidizers was more affected by the nutrientoptimized fertilization than the soil warming.

Keywords Ammonia-oxidizing archaea $\cdot$ Ammoniaoxidizing bacteria $\cdot$ Boreal forest $\cdot$ Fertilization $\cdot$ Long-term experiment $\cdot$ Soil warming

\section{Introduction}

Boreal forests have the lowest annual average temperatures after tundra and permanent ice caps and are considered to be the most sensitive ecosystem to global climate change among terrestrial forest ecosystems (Stewart et al. 1998). Research regarding effects of global change on soil microbial communities has focussed largely on community structure associated with a single environmental factor such as elevated $\left[\mathrm{CO}_{2}\right]$, nitrogen $(\mathrm{N})$ deposition, and warming. However, in these experiments, effects of associated global change factors potentially varied with treatment length and type, ecosystem and soil type, and other environmental conditions (Montealegre et al. 2000; Frey et al. 2008; Xu et al. 2009; Ge et al. 2010). Given that soil microorganisms are the key drivers of soil nutrient cycling (e.g., Falkowski et al. 2008), their roles in mediating climate change and ecosystem functioning are not well understood (Balser et al. 2001). An increasing number of reports have revealed shifts of carbon (C) substrate availability to microorganisms with temperature variations (e.g., MacDonald et al. 1995; Zogg et al. 1997; Flury and Gessner 2010), but there has been a lack of studies regarding effects of global warming on $\mathrm{N}$ cyclingassociated microbes (Avrahami et al. 2003; Horz et al. 2004; Tourna et al. 2008).

As an important process for global $\mathrm{N}$ cycling, nitrification involves two distinct steps: (1) oxidation of ammonia by ammonia-oxidizers, which possess ammonia monooxygenase genes and (2) oxidation of nitrite $\left(\mathrm{NO}_{2}{ }^{-}-\mathrm{N}\right)$ to nitrate $\left(\mathrm{NO}_{3}{ }^{-}-\mathrm{N}\right)$ by nitrite-oxidizing bacteria. Microbial ammonia oxidation has been thought to be solely carried out by bacteria before an ammonia-oxidizing archaeon (AOA) was reported (Könneke et al. 2005). More recently, two species of thaumarchaeota were isolated from a garden soil (Tourna et al. 2011) and an acid soil (Lehtovirta-Morley et al. 2011). To date, AOA have been found in various soils, where they outnumbered ammonia-oxidizing bacteria (AOB) (Leininger et al. 2006; He et al. 2007; Zhang et al. 2010). These findings indicate AOA as an important component of nitrification in terrestrial ecosystems. The abundance and community structure of $\mathrm{AOB}$ and $\mathrm{AOA}$ are affected by temperature (Avrahami et al. 2003; Tourna et al. 2008), ammonia availability (Kowalchuk and Stephen 2001), pH (He et al. 2007; Nicol et al. 2008), soil moisture (Hastings et al. 2000; Horz et al. 2004), and salinity (Bernhard et al. 2010). Allison and co-workers (Allison and Treseder 2008; Allison et al. 2008) indicated negative impacts of soil warming on the microbial abundance and activity and insignificant effect of $\mathrm{N}$ addition on microbial biomass and activity in a boreal forest soil. However, a recent study of soil microorganisms across Antarctic environments demonstrated soil warming increased the abundance of fungi and bacteria (Yergeau et al. 2011). No study has so far investigated potential interactive effects of soil warming and fertilization on ammonia-oxidizers in situ in a boreal forest soil.

This study examined the separate and combined effects of soil warming and fertilization on AOB and AOA abundance and community structure in a long-term field experiment in a boreal Norway spruce (Picea abies (L.) Karst.) forest. We hypothesized that fertilization or warming would not significantly affect the abundance and community structure of $\mathrm{AOB}$ and $\mathrm{AOA}$, while the interaction of fertilization and warming would lead to the shifts in the abundance and community structure of both AOB and AOA.

\section{Materials and methods}

\subsection{Site description}

The study area is located at Flakaliden long-term nutrient optimization experiment station in northern Sweden $\left(64^{\circ} 07^{\prime} \mathrm{N}, 19^{\circ} 27^{\prime} \mathrm{E}, 310 \mathrm{~m}\right.$ a. s. 1.). The site was planted with Norway spruce (P. abies (L.) Karst.), after clear-felling and prescribed burning in 1963. The climate is boreal, and mean annual temperature is $+2.3{ }^{\circ} \mathrm{C}$ (1990-2004), with mean monthly temperature between $-7.3^{\circ} \mathrm{C}$ in January and $+14.6^{\circ} \mathrm{C}$ in July (Slaney et al. 2007). The length of growing season (i.e., mean daily air temperature $>+5^{\circ} \mathrm{C}$ ) is approximately 140 days with a mean air temperature of $11.6^{\circ} \mathrm{C}$. Mean annual precipitation is ca. $600 \mathrm{~mm}$, one third falling as snow, which usually covers the frozen ground from mid-October to early May. Further details regarding the site and the treatments are provided in Linder (1995) and Bergh et al. (1999).

The treatments, which began in 1987, included untreated control plots $(C)$, irrigated plots $(I)$, and two nutrient optimization treatments, with either an annual application of solid fertilizers $(F)$ or a complete nutrient solution $(I L)$ supplied with the irrigation water every second day during the growing season (mid-June to mid-August). Treatments were replicated four times in a randomized block design, 
and each replicate consisted of $50 \times 50 \mathrm{~m}$ plots with $10 \mathrm{~m}$ wide buffer zones around the net plots.

\subsection{Soil warming and sampling}

In 1995, a soil-warming experiment was installed in the buffer zones of two $I$ and $I L$ stands, respectively. The warming experiment consisted of two $10 \times 10-\mathrm{m}$ heated plots on each treatment $\left(I_{\mathrm{h}}\right.$ and $\left.I L_{\mathrm{h}}\right)$. Heated plots had paired control plots $\left(I_{\mathrm{c}}\right.$ and $\left.I L_{\mathrm{c}}\right)$, chosen for their similarity in basal area. Soils were warmed using heating cables inserted under the humus layer at intervals of ca. $20 \mathrm{~cm}$. The soil warming started in April each year, around 1 month before soil thawed in unheated plots. Soil temperature was increased $1{ }^{\circ} \mathrm{C}$ per week, until a $5^{\circ} \mathrm{C}$ difference was reached between warmed and control plots. A temperature difference of $5^{\circ} \mathrm{C}$, between heated $\left(I_{\mathrm{h}}\right.$ and $\left.I L_{\mathrm{h}}\right)$ and control plots $\left(I_{\mathrm{c}}\right.$ and $\left.I L_{\mathrm{c}}\right)$, was maintained during the growing season. In late autumn, when soil temperature on the control plots approached $0^{\circ} \mathrm{C}$, the soil temperature of warmed plots was reduced by $1{ }^{\circ} \mathrm{C}$ per week until they were the same as unheated control plots. Detailed descriptions of design and performance of the soilwarming system are found in Bergh and Linder (1999) and Strömgren and Linder (2002).

In August 2006 (after 12 seasons of warming), five subsamples of the topsoil $(0-10 \mathrm{~cm})$ were collected from each subplot and treatment and mixed to form one composite sample per plot. Samples were placed in sterile plastic bags, sealed, and stored in a freezer at $-20^{\circ} \mathrm{C}$ until transported and packed in dry ice, to the laboratory at Griffith University, Australia. Samples were passed through a $2.0-\mathrm{mm}$ sieve and stored at $-80^{\circ} \mathrm{C}$ prior to DNA analysis.

\subsection{Soil DNA extraction and amoA genes-PCR}

Nucleic acids of the soils $(0.3 \mathrm{~g})$ were extracted using the MoBio Powersoil DNA Isolation Kit (Carlsbad, USA) according to manufacturer's instruction. Primer pairs used for polymerase chain reaction (PCR) of $\mathrm{AOB}$ and $\mathrm{AOA}$ amoA genes were amoA1F (GGG GTT TCT ACT GGT GGT)/amoA2R (CCC CTC KGS AAA GCC TTC TTC), and CrenamoA23F (ATG GTC TGG CTW AGA CG)/ CrenamoA616R (GCC ATC CAT CTG TAT GTC CA), respectively (Tourna et al. 2008). The thaumarchaeal amoA gene were amplified as follows: an initial denaturation step at $95^{\circ} \mathrm{C}$ for $2 \mathrm{~min} ; 35$ cycles of $95^{\circ} \mathrm{C}$ for $30 \mathrm{~s}, 55^{\circ}$ $\mathrm{C}$ for $45 \mathrm{~s}, 72^{\circ} \mathrm{C}$ for $0 \mathrm{~s}$, and final extension at $72^{\circ} \mathrm{C}$ for $60 \mathrm{~s}$. The $50-\mu \mathrm{L}$ reaction mixture contained $10 \mu \mathrm{L} 5 \times$ GoTaq Flexi Green Buffer (Promega), $2.5 \mathrm{mM} \mathrm{MgCl} 2,750 \mu \mathrm{M}$ each dNTP, $100 \mu \mathrm{M}$ each primer, 1.25 units GoTaq DNA polymerase (Promega), $0.5 \mu \mathrm{L}$ template DNA, and ultraclean water to volume. All PCR products were checked via $1 \%$ agarose gel electrophoresis.
2.4 Establishment of $\mathrm{AOB}$ and $\mathrm{AOA}$ amoA gene fragment libraries and identification of associated genotypes

The amplicons of amoA genes were purified using a QIAquick Gel Extraction Kit (Qiagen, Valencia, CA). PCR products were cloned into the pGEM $^{\circledR}-\mathrm{T}$ Easy Vector System and propagated with JM109 Competent Cells (Promega, Madison, WI) following manufacturer's instruction. Both amoA genes of AOB and AOA clone libraries were established from each sample. Sixty positive colonies were randomly selected and were checked with $\mathrm{T} 7$ ( T A A T A C G A C T C A C T A T A G G G ) / S p 6 (ATTTAGGTGACACTATAG) primers. Representative genotypes were determined via restriction fragment length polymorphism (RFLP). Amplimers with corrected size were digested using MboI (NEB) for AOB, and MboI (NEB) and HaeIII (NEB) for AOA. Restriction fragments were screened on a $3 \%$ agarose gel, running at $100 \mathrm{~V}$ in $1 \times \mathrm{TAE}$ buffer for $60 \mathrm{~min}$ and digitally photographed using ChemiDocTM XRS imaging system (Bio-Rad). The amoA gene RFLP patterns were checked using Quantity-One software (Bio-Rad).

\subsection{Putative amoA gene sequencing}

All plasmid DNA of representative RFLP patterns were amplified using BigDye Terminator v3.1 Cycle Sequencing kits (Applied Biosystems), according to manual's instruction. Approximately $20 \mu \mathrm{L}$ PCR products were purified using the ethanol/EDTA/sodium acetate precipitation method and sequenced using a $3130 \times 1$ Genetic Analyzer (Applied Biosystems). Accession numbers are HM131544-HM131546 for bacterial amoA gene and HM131579-HM131599 for archaeal amoA gene.

\subsection{Quantitative PCR}

Real-time PCR was performed in a $20-\mu \mathrm{L}$ reaction mixture containing $10 \mu \mathrm{L}$ SYBR $^{\circledR}$ Premix Ex Taq ${ }^{\mathrm{TM}}$ (Perfect Real Time) (Takara Bio), $200 \mu \mathrm{M}$ each primer, and $2 \mu \mathrm{L}$ template DNA solution by a Mastercycler ep Realplex2 thermocycler (Eppendorf). Universal primer pairs 338f (ACT CCT ACG GGA GGC AG)/518r (ATT ACC GCG GCT GCT GG) and A109f (ACK GCT CAG TAA CAC GT)/A334r (TCG CGC CTG CTG CTC CCC GT) (Sun et al. 2009) were used to determine population size of total bacteria and archaea, respectively. The standard template plasmid DNA was diluted in a $10^{-1}$ to $10^{-8}$ series using EASY Dilution (for Real Time PCR) (Takara). Clones (FE2WH1B_17 and FE2WH1B_26) were serially diluted for use as the standard templates. Standard plasmid DNA was prepared using the QIAprep Spin Miniprep Kit (QIAGEN), with concentration determined using a NanoDrop 2000 UV-vis Spectrophotometer (Thermo 
Scientific). The PCR conditions for thaumarchaeal amoA (AOA) gene were as follows: an initial denaturation step at $95^{\circ} \mathrm{C}$ for $2 \mathrm{~min} ; 40$ cycles of $95^{\circ} \mathrm{C}$ for $15 \mathrm{~s}$, $55^{\circ} \mathrm{C}$ for $30 \mathrm{~s}, 72^{\circ} \mathrm{C}$ for $45 \mathrm{~s}, 80^{\circ} \mathrm{C}$ for $20 \mathrm{~s}$, and final extension at $72^{\circ} \mathrm{C}$ for $60 \mathrm{~s}$, followed by a melting curve cycle. The fluorescence intensity was detected at $80^{\circ} \mathrm{C}$. The thermal protocol for AOB was same with AOA except the annealing temperature was decreased from $55^{\circ} \mathrm{C}$ to $53^{\circ} \mathrm{C}$. The effect of soil inhibitors on PCR was tested in a dilution series of 10-, 20-, and 50-fold of the extracted DNA in the presence and absence of bovine serum albumin. Quantitative PCR was performed on purified template plasmid DNA to make a standard curve with a log-linear effect of target concentration $\left(r^{2}=0.999\right)$ and an amplification efficiency of 0.960 .

\subsection{Statistical and phylogenetic analysis}

Results of real-time PCR were analyzed via analysis of variance with split-plot model, as well as a generalized linear model. The unit of replication for the heating factor was the blocks $(n=2)$ (Strömgren and Linder (2002). Multivariate analyses were performed using canonical correspondence analysis (CCA) with Brodgar version 2.6.6 (Highland Statistics Ltd. UK); $P$ values $\leq 0.05$ were considered significant. DNA sequences were aligned using ClustalW (Thompson et al. 1994) and alignments edited using Bioedit sequence alignment editor 7.0.5 (Hall 1999). The maximum-likelihood method was followed to construct the phylogenetic tree using MEGA5 (Kumar et al. 2008) and based on the Jukes-Cantor model with 1,000 bootstrap replicates for calculating the evolutionary distance.

\section{Results}

\subsection{Abundance of soil bacteria and archaea}

Bacterial 16S rRNA gene abundance ranged from $1.32 \times 10^{8}$ to $7.08 \times 10^{8}$ copies $\mathrm{g}^{-1}$ dry soil, while archaeal $16 \mathrm{~S}$ rRNA gene abundance ranged from $0.18 \times 10^{7}$ to $1.91 \times 10^{7}$ copies $g^{-1}$ dry soil (Fig. 1a). Fertilization in the nonheated plots $\left(I L_{\mathrm{c}}\right)$ significantly decreased abundance of bacteria compared with $I_{\mathrm{c}}, I_{\mathrm{h}}$, and $I L_{\mathrm{h}}$ treatments (see Fig. 1a), while bacterial abundance in $I L_{\mathrm{h}}$ was significantly higher than in the $I L_{\mathrm{c}}$ treatment. Bacterial abundance reflected an interactive effect of soil warming and fertilization $(P<0.001)$ and indicated that the effect of fertilization was mitigated by soil warming $\left(I L_{\mathrm{h}}>I L_{\mathrm{c}}\right)$. No significant differences or interaction effects $(P>0.05)$ were detected in archaeal 16S rRNA gene abundance (see Fig. 1a).
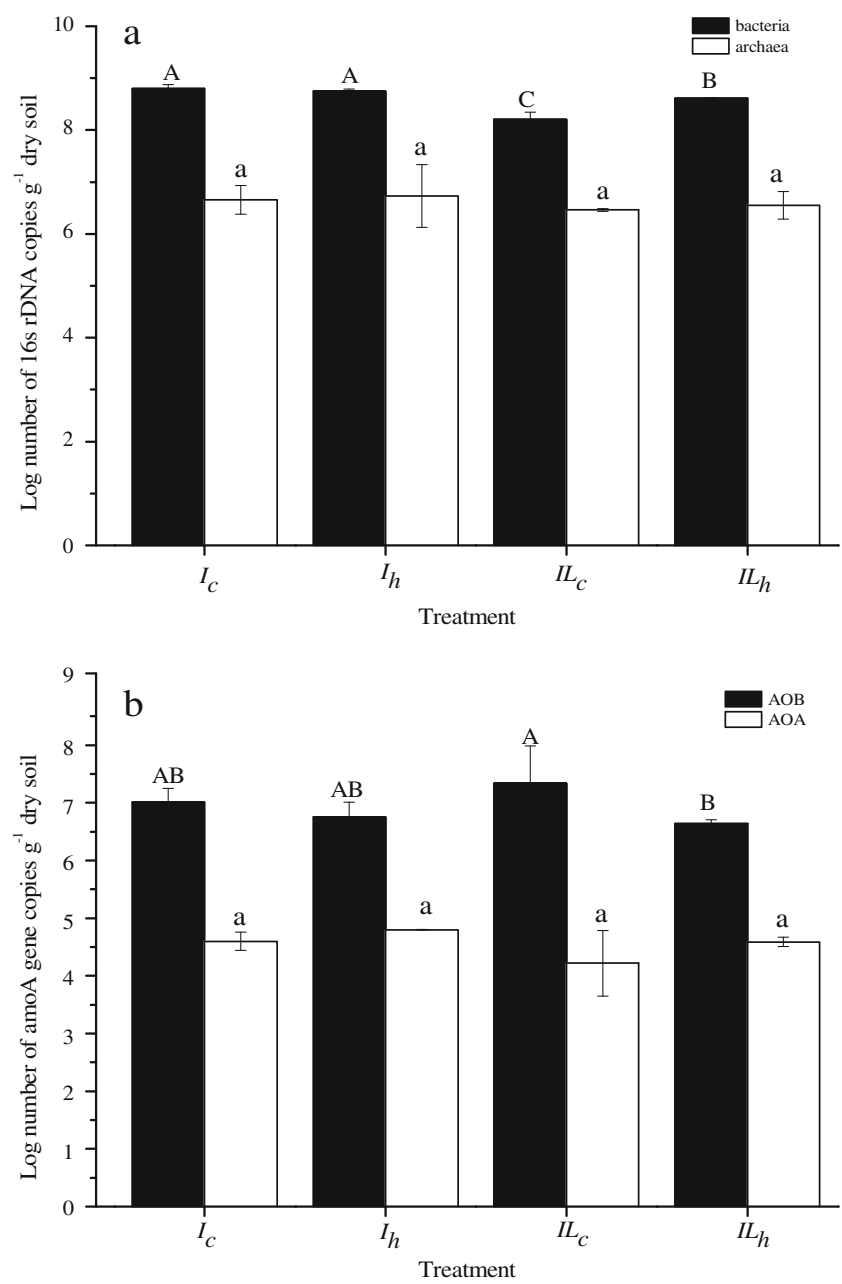

Fig. 1 The effect of soil-warming, with (IL) or without fertilization (I) on: a Bacterial and archaeal 16S rRNA gene copy numbers and b ammonia-oxidizing bacteria (AOB) and ammonia-oxidizing archaea (AOA) amoA gene copy numbers. The treatments were: irrigation, no warming $\left(I_{\mathrm{c}}\right)$; irrigation, warming $\left(I_{\mathrm{h}}\right)$; irrigation + fertilization, no warming $\left(I L_{\mathrm{c}}\right)$, and irrigation+fertilization, warming $\left(I L_{\mathrm{h}}\right)$

\subsection{Abundances of soil AOB and AOA}

Bacterial amoA gene abundance was in the range of $0.32 \times$ $10^{7}$ to $8.71 \times 10^{7}$ copies $\mathrm{g}^{-1}$ dry soil across all treatments, much higher than thaumarchaeal amoA gene abundance $\left(0.66 \times 10^{4}-6.31 \times 10^{4}\right.$ copies $g^{-1}$ dry soil; Fig. $\left.1 b\right)$. There was a similar number of bacterial amoA gene copies in $I_{\mathrm{h}}$ and $I_{\mathrm{c}}$ treatments (i.e., $I_{\mathrm{h}}=I_{\mathrm{c}}$ ), but a higher number with fertilization alone $\left(I L_{\mathrm{c}}\right)$ than with combined soil warming and fertilization $\left(I L_{\mathrm{h}}\right)$, i.e., $I L_{\mathrm{h}}<I L \mathrm{c}, P=0.044$ (see Fig. $1 \mathrm{~b}$ ). Effects of soil warming and fertilization on the number of thaumarchaeal amoA gene copies were statistically insignificant $(P>0.05)$. Ammonia-oxidizers were dominated by AOB across all treatments, with mean ratios of AOA to AOB ranging from $0.001\left(I L_{\mathrm{c}}\right)$ to $0.017\left(I_{\mathrm{h}}\right)$ (Fig. 2). The ratios of AOA to archaea ranged from 0.014 to 0.025 , with no significant differences across different treatments (see 


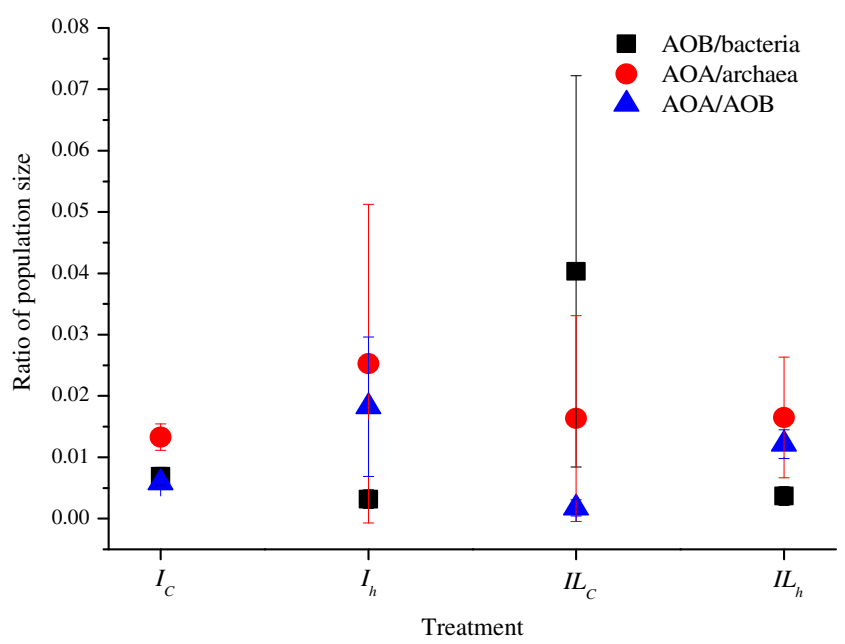

Fig. 2 Effects of soil warming and fertilization on the abundance ratio of $\mathrm{AOB} /$ bacteria, $\mathrm{AOA} /$ archaea, and $\mathrm{AOB} / \mathrm{AOA}$

Fig. 2). The ratios of AOB to bacteria were greater in the $I L \mathrm{c}$ treatment than other treatments (see Fig. 2).

\subsection{Community analysis of AOB and AOA}

Community structure analyses of $\mathrm{AOB}$ and $\mathrm{AOA}$ were based on the clone library followed by RFLP for screening of clones and selection of different clones for sequencing. About three duplicates of unique genotypes were selected from each library for sequencing (in total 61 and 28 sequences of $\mathrm{AOA}$ and $\mathrm{AOB}$, respectively). Chimeric sequences were excluded from analysis, leaving 72 of 89 selected clones for phylogenetic analysis. In this study, amo $A$ genes that shared at least 97\% homology of nucleic acid sequence were defined as one genotype or operational taxonomic unit (OTU). Phylogenetic trees of the bacterial and thaumarchaeal $a m o A$ gene sequences and related GenBank sequences are shown in Figs. 3 and 4. All bacterial amo $A$ gene

Fig. 3 Maximum likelihood distance tree based on an alignment of $413 \mathrm{bp}$ bacterial amo $A$ gene sequences. The sequences obtained in this study are indicated in bold including the following information: clone name, accession number in GenBank, and treatments in the parentheses. Nitrosococcus oceanus was used as the outgroup sequence. Bootstrap values $(>60 \%)$ are indicated at branch points. The scale bar represents $5 \%$ sequence divergence sequences fell within three groups: (1) amoA cluster 1, with Nitrosospira sp. Ka3 as a representative pure culture; (2) amoA cluster 2, with Nitrosospira sp. L115 as a representative pure culture; and (3) amoA cluster 9, with environmental clone w923 (AF353259) as a reference sequence (Avrahami et al. 2003). Bacterial amo $A$ cluster 1 was observed only in the sample from the unheated and unfertilized treatment $\left(I_{\mathrm{c}}\right)$ (Figs. 3 and 5a). Meanwhile, bacterial amo $A$ sequences affiliated with cluster 2 were present in all treatments, but the only genotype observed in the fertilized treatments (i.e., $I L_{\mathrm{h}}$ and $\left.I L_{\mathrm{c}}\right)$. The community structures of most samples in all the treatments were dominated by bacterial amo $A$ sequences affiliated with cluster 2 (89-100\%) (see Fig. 5a).

For thaumarchaeal amo $A$ genes, 29 clones, which covered all treatments, fell within soil cluster 2 and soil cluster 5 . Soil cluster 2 included nine OTUs and a representative pure culture ammonia-oxidizing archaeon 'Candidatus Nitrososphaera gargensis' (clone_GA15P03) that is affiliated with Thaumarchaeota group 1.1b (Hatzenpichler et al. 2008). The thaumarchaeal amo $A$ sequences occurred at a higher frequency in soil cluster 5 than in soil cluster 2 (see Fig. 5b). The OTUs in the fertilized treatments were relatively higher than those in the unfertilized treatments (see Fig. 4).

3.4 Difference in AOB and AOA communities in response to environmental factors

Six major environmental factors (heated, fertilized, $\mathrm{NH}_{4}^{+}-\mathrm{N}, \mathrm{pH}$, total carbon, and total nitrogen) and OTUs were included in the CCA. The first two axes of the CCA of the AOB communities versus environmental factors explained $92.4 \%$ of the total variance in the amo $A$ genotypes composition and $100 \%$ of the cumulative variance of the genotype-environment relationship (Fig. 6a). Fertilization ( $F=2.722, P=0.001,1,000$ permutations) was the most influential environmental gradient on the distribution

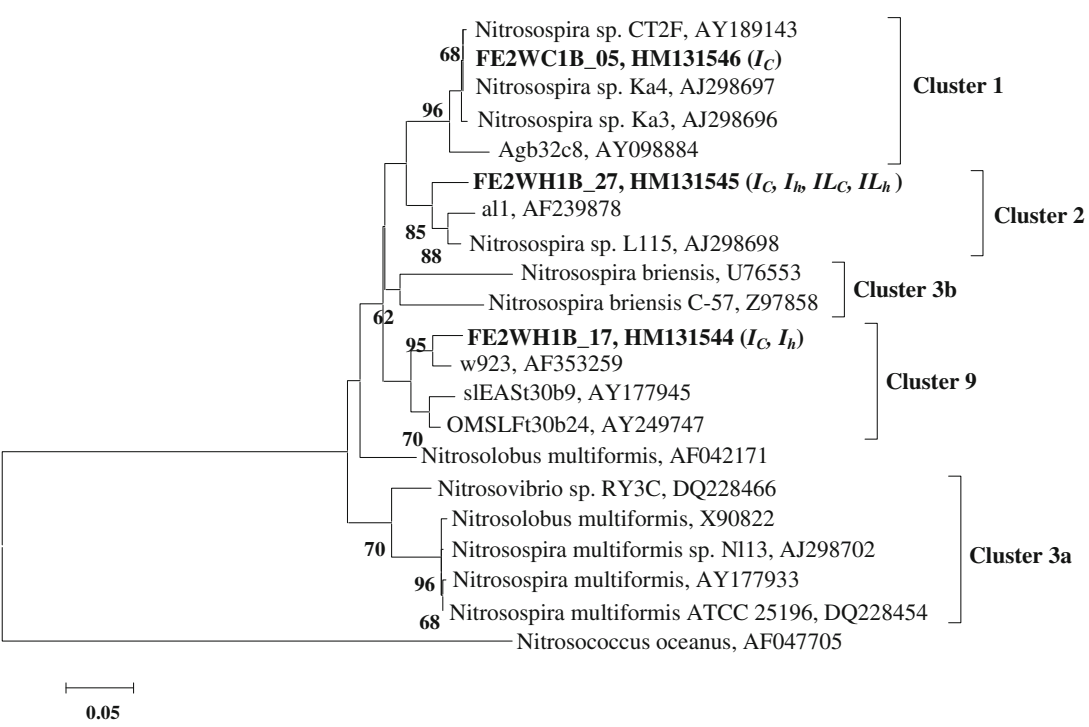


Fig. 4 Maximum likelihood distance tree based on an alignment of $559 \mathrm{bp}$ archaeal amo $A$ gene sequences. The sequences obtained in this study are in bold including the following information: clone name, accession number in GenBank, and treatments in parentheses. Bootstrap values $(>60 \%)$ are indicated at branch points. The bar shows a relative distance of 0.05

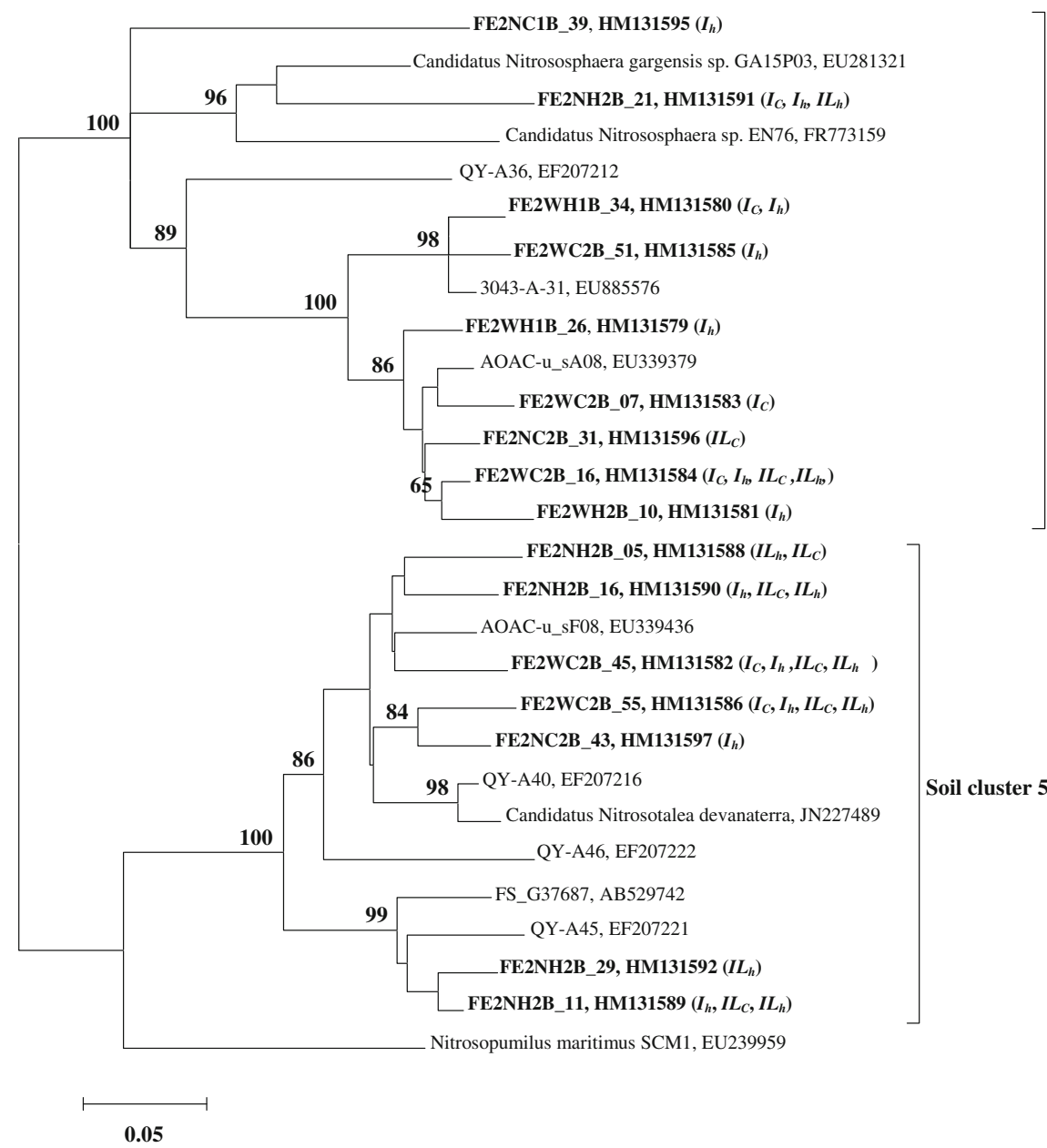

Soil cluster 2 of amoA gene of AOB among the samples, followed by soil warming $(F=2.114, P=0.148)$ and $\mathrm{pH}$ value $(F=2.091, P=$ $0.157)$. In addition, $33.8 \%$ and $21.1 \%$ of the variance in the AOB OTUs could be explained by fertilization or soil warming alone. In comparison, the first two axes of the CCA of the AOA communities versus environmental factors explained $56.9 \%$ of the total variance in the amo $A$ genotypes composition and $68.8 \%$ of the cumulative variance of the genotype-environment relationship (see Fig. 6b). The CCA showed that fertilization had the highest correlations with the OTU composition of AOA among the six factors tested ( $F=2.430, P=0.033,1,000$ permutations), followed by the $\mathrm{pH}$ value $(F=1.215, P=0.311)$. Fertilization and $\mathrm{pH}$ explained $34.9 \%$ and $31.0 \%$ of the variance in the AOA genotypes or OTUs, respectively.

\section{Discussion}

4.1 Responses of AOB and AOA abundance to soil warming and fertilization

Our results show that long-term soil warming mitigated the reduction of soil bacteria abundance by fertilization, but neither treatments affected soil archaeal abundance (see Fig. 1a). Our findings are consistent with Shen et al. (2010) and He et al. (2007), who reported decreased soil bacterial abundance related to $\mathrm{N}$ fertilization in arable soils. Negative effects of fertilization on bacteria were also reported by Ekblad and Nordgren (2002) and Demoling et al. (2008), which indicates that $\mathrm{C}$ limitation rather than $\mathrm{N}$ limitation affects microbial abundance and activity in coniferous forest soils. Soil organic matter is sensitive to global warming, especially in boreal ecosystems (e.g., Jarvis and Linder 2000; Melillo et al. 2002; Davidson and Janssens 2006). Studies in three forest ecosystems indicated that shifts of soil $\mathrm{C} / \mathrm{N}$ ratio, soil acidification, and root exudation reduction induced by $\mathrm{N}$ saturation caused bacterial biomass decreasing under long-term fertilization (Wallenstein et al. 2006).

Nitrogen fertilization has previously been shown to increase the abundance of soil AOB, which dominated N-rich environments (Di et al. 2009; Hallin et al. 2009). However, we observed an insignificant effect of fertilization on AOB and AOA abundance (see Fig. 1b). A 50-year-old fertilization experiment showed that amoA gene copy numbers of $\mathrm{AOB}$ and $\mathrm{AOA}$ under several fertilized treatments were 

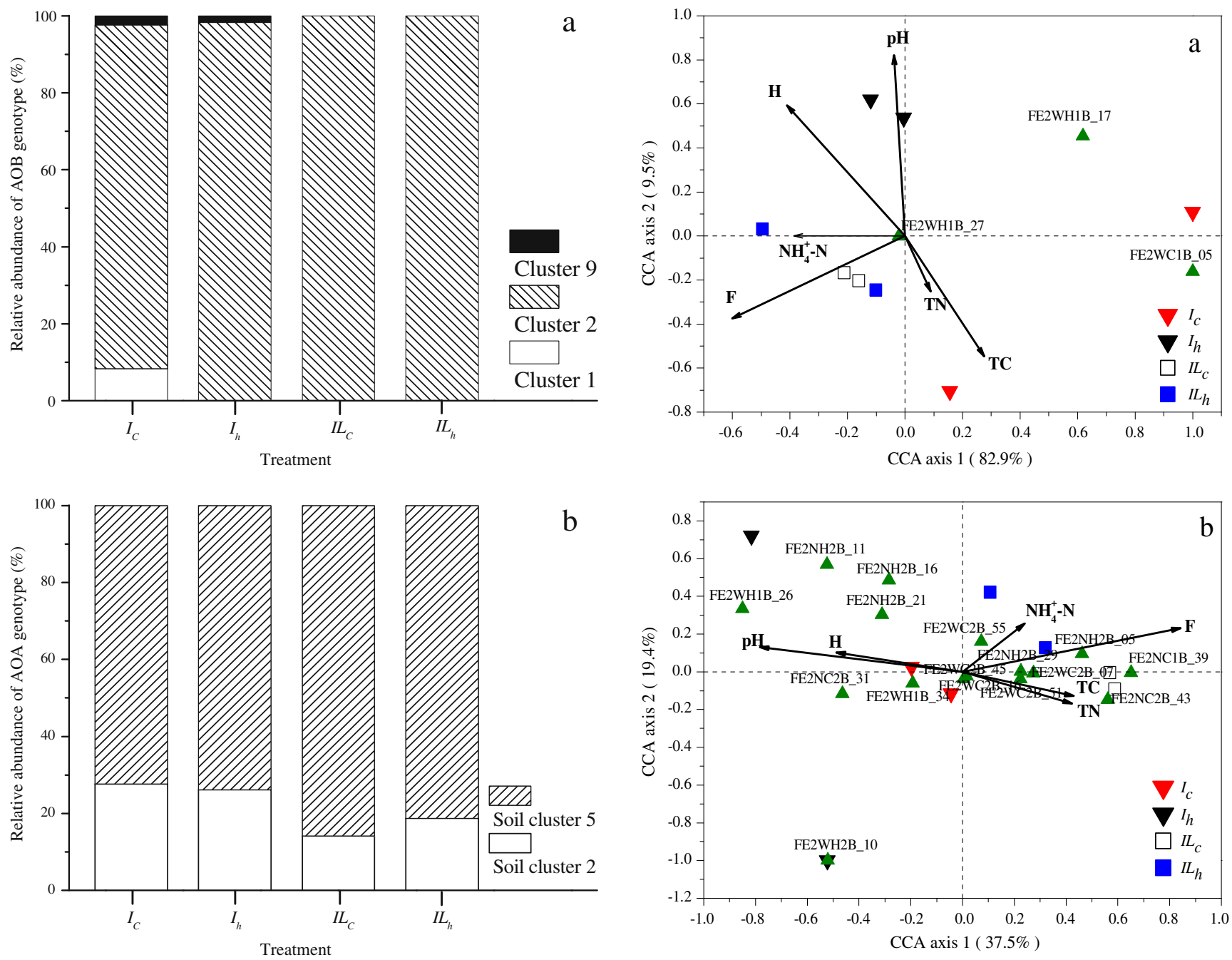

Fig. 5 Effects of soil warming and fertilization on the relative abundance of AOA and AOB. a Relative abundance of AOB clusters 1, 2, and 9 and b relative abundance of AOA cluster 2 and cluster 5. Abundance of genotype is calculated as proportion of analyzed clones affiliated with the fragment patterns belonging to one of the clusters among the clone numbers used in the digestion analysis in one clone library

insignificant, except for the ammonium sulfate treatment (Hallin et al. 2009). That difference may be explained by the fact that the application of ammonium sulfate would lower the soil $\mathrm{pH}$ value. However, the abundance of ammonia oxidizers also depended on the soil sampling layer and plant species present (Priha and Smolander 1999). Our results show that soil warming did not significantly change the amoA gene copy numbers of AOA (see Fig. 1b), which is consistent with the result from an elevated temperature experiment in a pristine forest soil (Szukics et al. 2010) and that the amoA gene copy numbers of AOB decreased significantly with fertilization (i.e., $\mathrm{HF}<\mathrm{F}$, Fig. 1b). The effects of temperature on the amoA gene copy numbers of AOB and AOA have been observed in seasonal or altitude changes (He et al. 2007; Zhang et al. 2009; Rasche et al. 2011). For

Fig. 6 Canonical correspondence analysis (CCA) ordination plots for the first two dimensions of CCA of the relationship between: a the distribution of AOB OTUs with environmental factors and $\mathbf{b}$ the distribution of AOA OTUs with environmental factors. The optimal CCA models represented by the diagrams were produced with standardization explanatory variables by weighting and scaling of scores focused on inter-species correlations via $F$-statistic significant tests. The eigenvalues of the first two axes (CCA1 and CCA2) were 0.070 and 0.008 , respectively for $\mathbf{a}$, and 0.220 and 0.114 , respectively, for $\mathbf{b}$. Correlations between environmental variables and CCA axes are represented by the length and angle of lines (environmental factor vectors). The green triangles represent the genotype of amoA genes

example, $\mathrm{AOB}$ and $\mathrm{AOA}$ amoA gene copy numbers have been found to be higher in summer than winter in a Chinese upland red soil (He et al. 2007).

Temperature has a negative correlation with bacterial amo $A$ gene copy numbers and a positive correlation with thaumarchaeal amo $A$ gene copy numbers in a temperate beech forest soil (Rasche et al. 2011). The AOA amoA gene copy numbers decreased along an altitudinal gradient of Mount Everest, whereas that of AOB did not shift significantly with altitude (Zhang et al. 2009). More recently, a study in the rhizosphere of a boreal forest tree indicated a 
decrease of archaeal diversity under soil warming (Bomberg et al. 2011) which is consistent with previous findings in a receding glacier foreland of Austria (Nicol et al. 2005, 2006). In addition, soil moisture has been reported as a major factor affecting soil $\mathrm{N}$ mineralization, which influences the $\mathrm{N}$ availability, along a temperature gradient in four European shrubland ecosystems (Beier et al. 2008). This mechanism was unlikely to be significant in our study area, where soil moisture was relatively similar among all treatments (Strömgren and Linder 2002). In boreal forest ecosystems, growth of soil microorganisms was found to primarily be controlled by $\mathrm{C}$ rather than $\mathrm{N}$ availability (Ekblad and Nordgren 2002). With the temperature increasing, the ammonia oxidizers, especially the $\mathrm{AOB}$, may not be the winner in the resource competition with plants or other fast-growing microbes (Kaye and Hart 1997; Zogg et al. 1997).

\subsection{Responses of AOB and AOA community structure} to soil warming and fertilization

Phylogenetic analyses of bacterial amoA genes showed that Nitrosospira cluster 2 was the only genotype detectable in the fertilization treatments, which dominated across all treatments (see Figs. 2 and 4a). CCA analysis also indicated a positive relationship between dominant OTUs (FE2WH1B_27, Nitrosospira cluster 2) and fertilization (see Fig. 6a). Our findings can be related to previous findings regarding the ubiquity of Nitrosospira cluster 2 sequences in nine northern and western European soils (Nugroho et al. 2005). However, a denaturing gradient gel electrophoresis (DGGE) analysis of PCR products of both 16S rRNA gene and amoA gene of AOB in grassland revealed that Nitrosospira cluster 3 and Nitrosomonas cluster 7 dominated the ammonia-oxidizing bacteria after the addition of $\mathrm{N}$ fertilizer (Webster et al. 2002). Indeed, Nitrosospira, rather than the more widely studied genus Nitrosomonas, are considered as the dominant soil AOB in terrestrial ecosystems (Kowalchuk et al. 2000; Phillips et al. 2000). For the effect of $\mathrm{N}$ fertilizer addition on the ammonia-oxidizing archaea community composition, Nicol et al. (2003) found that a shift of group 1.1b crenarchaeotes between $\mathrm{N}$ fertilizer addition plots and non-fertilization plots in three grassland soil types, which was based on an analysis of both 16S rRNA and 16S rDNA-derived DGGE profiles. In a microcosm study conducted by Avrahami et al. (2003), a shift of dominant Nitrosospira clusters was observed in response to increasing soil temperature. Our results also show a shift of Nitrosospira cluster under soil warming (see Fig. 5a). In addition, Nitrosospira cluster 2 and cluster 1 were detected in control treatments $\left(I_{\mathrm{c}}\right.$ and $\left.I L_{\mathrm{c}}\right)$, consistent with the finding by Avrahami and Conrad (2005) who reported that Nitrosospira clusters 1,2, and 4 were dominant in soils from cold-temperate regions, while Nitrosospira clusters 3a, 3b, and 9-12 were mostly found in warmer regions. Only one or two clones of
Nitrosospira cluster 9 were observed in the control, and soilwarming treatment, indicating that numbers of Nitrosospira clusters, which are widely distributed in soils of warmtemperate regions, were below the detection limit. Richness of soil cluster 5 of AOA in the $I L_{\mathrm{c}}$ and $I L_{\mathrm{h}}$ treatments was higher than that of soil cluster 2, which have been retrieved from various soils and sediments (Leininger et al. 2006; He et al. 2007), in the treatments without fertilization (see Figs. 4 and 5b). Finally, CCA analysis showed that fertilization was the major factor affecting AOA community structure, and there was a positive relationship between dominant AOA genotypes and fertilization (see Fig. 5b). Tourna et al. (2008) detected a change of AOA community with increasing soil temperature by DGGE technology. Results from CCA showed that six (FE2WH1B_26, FE2NH2B_11, FE2NH2B_16, FE2NH2B_21, FE2NC2B_31, and FE2WH1B_34) of the 16 were positively correlated with the soil warming (see Fig. 6b). A study by Urakawa et al. (2008) showed that the phylogenetic diversity of both AOB and AOA decreased under a low temperature aquarium biofiltration system. In the present study, the number of AOA genotype was significantly higher than that of AOB (see Figs. 3 and 4), but lack significant change between different treatments in this boreal forest soil. A previous study has indicated that the ammonia oxidizer Thaumarchaeota has a greater range of temperature adaptability than the ammonia oxidizer bacteria (Erguder et al. 2009).

\section{Conclusions}

This study demonstrated that, in a boreal forest soil, the abundance of both bacterial and thaumarchaeal amoA genes was not affected by fertilization or warming alone, but the interaction of fertilization and warming reduced the abundance of bacterial amoA genes. Phylogenetic analysis showed that Nitrosospira cluster 2 and soil cluster 5 were the dominant groups in this boreal forest soil. The community composition of ammonia-oxidizers was more affected by the nutrientoptimized fertilization than the soil warming. The AOB may be the main contributor of nitrification in boreal forest ecosystems. However, it is acknowledged that this study is limited by the number of the replication (two), and therefore results of this study should be case-specific. Further study is needed to investigate the abundance and community composition of other $\mathrm{N}$ cycle associated microbes in response to the global climate change and forest management practices for sustainability of boreal forest ecosystems.

Acknowledgments This research was jointly supported by Australian Research Council (FT0990547; DP0664154; DP1092470), Chinese Academy of Sciences (KZCX2-YW-JC401), Natural Science Foundation of China (41020114001, 41025004), and the Swedish University of Agricultural Sciences. Initial establishment and maintenance of the long-term soil-warming experiment was supported by the former 
Swedish Council of Forestry and Agricultural Research (SJFR) and later by the Swedish Research Council for Environment, Agricultural Sciences, and Spatial Planning (FORMAS).

\section{References}

Allison SD, Treseder KK (2008) Warming and drying suppress microbial activity and carbon cycling in boreal forest soils. Glob Chang Biol 14:2898-2909

Allison SD, Czimczik CI, Treseder KK (2008) Microbial activity and soil respiration under nitrogen addition in Alaskan boreal forest. Glob Chang Biol 14:1156-1168

Avrahami S, Conrad R (2005) Cold-temperate climate: a factor for selection of ammonia oxidizers in upland soil? Can J Microbiol 51:709-714

Avrahami S, Liesack W, Conrad R (2003) Effects of temperature and fertilizer on activity and community structure of soil ammonia oxidizers. Environ Microbiol 5:691-705

Balser TC, Kinzig AP, Firestone MK (2001) Linking soil microbial communities and ecosystem functioning. In: Kinzig A, Tilman D, Pacala P (eds) The functional consequences of biodiversity: empirical progress and theoretical extensions. Princeton University Press, Princeton, pp 265-293

Beier C, Emmett BA, Peñuelas J, Schmidt IK, Tietema A, Estiarte M, Gundersen P, Llorens L, Riis-Nielsen T, Sowerby A, Gorissen A (2008) Carbon and nitrogen cycles in European ecosystems respond differently to global warming. Sci Total Environ 407:692-697

Bergh J, Linder S (1999) Effects of soil warming during spring on photosynthetic recovery in boreal Norway spruce stands. Glob Chang Biol 5:245-253

Bergh J, Linder S, Lundmark T, Elfving B (1999) The effect of water and nutrient availability on the productivity of Norway spruce in northern and southern Sweden. For Ecol Manag 119:51-62

Bernhard AE, Landry ZC, Blevins A, de la Torre JR, Giblin AE, Stahl DA (2010) Abundance of ammonia-oxidizing archaea and bacteria along an estuarine salinity gradient in relation to potential nitrification rates. Appl Environ Microb 76:1285-1289

Bomberg M, Münster U, Pumpanen J, Ilvesniemi H, Heinonsalo J (2011) Archaeal communities in boreal forest tree rhizospheres respond to changing soil temperatures. Microbiol Ecol 62:205-217

Davidson EA, Janssens IA (2006) Temperature sensitivity of soil carbon decomposition and feedbacks to climate change. Nature 440:165-173

Demoling F, Nilsson LO, Bååth E (2008) Bacterial and fungal response to nitrogen fertilization in three coniferous forest soils. Soil Biol Biochem 40:370-379

Di HJ, Cameron KC, Shen JP, Winefield CS, O'Callaghan M, Bowatte S, He JZ (2009) Nitrification driven by bacteria and not archaea in nitrogen-rich grassland soils. Nat Geosci 2:621-624

Ekblad A, Nordgren A (2002) Is growth of soil microorganisms in boreal forests limited by carbon or nitrogen availability? Plant Soil 242:115-122

Erguder TH, Boon N, Wittebolle L, Marzorati M, Verstraete W (2009) Environmental factors shaping the ecological niches of ammonia oxidizing archaea. FEMS Microbiol Rev 33:855-869

Falkowski PG, Fenchel T, Delong EF (2008) The microbial engines that drive Earth's biogeochemical cycles. Science 320:1034-1039

Flury S, Gessner MO (2010) Experimentally simulated globalwarming and nitrogen-enrichment effects on microbial litter decomposers in a marsh. Appl Environ Microb 77:803-809

Frey SD, Drijber R, Smith H, Melillo J (2008) Microbial biomass, functional capacity, and community structure after 12 years of soil warming. Soil Biol Biochem 40:2904-2907
Ge Y, Chen CR, Xu ZH, Oren R, He JZ (2010) The spatial factor, rather than elevated $\mathrm{CO}_{2}$, controls the soil bacterial community in a temperate forest ecosystem. Appl Environ Microb 76:74297436

Hall TA (1999) BioEdit: a user-friendly biological sequence alignment editor and analysis program for Windows 95/98/NT. Nucleic Acids Symp Ser 41:95-98

Hallin S, Jones CM, Schloter M, Philippot L (2009) Relationship between $\mathrm{N}$-cycling communities and ecosystem functioning in a 50-year-old fertilization experiment. ISME J 3:597-605

Hastings RC, Butler C, Singleton I, Saunders JR, McCarthy AJ (2000) Analysis of ammonia oxidizing bacteria populations in acid forest soil during conditions of moisture limitation. Lett Appl Microbiol 30:14-18

Hatzenpichler R, Lebedeva EV, Spieck E, Stoecker K, Richter A, Daims H, Wagner M (2008) A moderately thermophilic ammonia-oxidizing crenarchaeote from a hot spring. Proc Natl Acad Sci USA 105:2134-2139

He JZ, Shen JP, Zhang LM, Zhu YG, Zheng YM, Xu MG, Di HJ (2007) Quantitative analyses of the abundance and composition of ammonia-oxidizing bacteria and ammonia-oxidizing archaea of a Chinese upland red soil under long-term fertilization practices. Environ Microbiol 9:2364-2374

Horz HP, Barbrook A, Field CB, Bohannan BJM (2004) Ammoniaoxidizing bacteria respond tomultifactorial global change. Proc Natl Acad Sci USA 101:15136-15141

Jarvis P, Linder S (2000) Botany: constraints to growth of boreal forests. Nature 405:904-905

Kaye JP, Hart SC (1997) Competition for nitrogen between plants and soil microorganisms. Trends Ecol Evol 12:139-143

Könneke M, Bernhard AE, José R, Walker CB, Waterbury JB, Stahl DA (2005) Isolation of an autotrophic ammonia-oxidizing marine archaeon. Nature 437:543-546

Kowalchuk GA, Stephen JR (2001) Ammonia-oxidizing bacteria: a model for molecular microbial ecology. Annu Rev Microbiol $55: 485-529$

Kowalchuk GA, Stienstra AW, Heilig GHJ, Stephen JR, Woldendorp JW (2000) Molecular analysis of ammonia oxidising bacteria in soil of successional grasslands of the Drentsche A (The Netherlands). FEMS Microbiol Ecol 31:207-215

Kumar S, Nei M, Dudley J, Tamura K (2008) MEGA: a biologistcentric software for evolutionary analysis of DNA and protein sequences. Brief Bioinform 9:299-306

Lehtovirta-Morley LE, Stoecker K, Vilcinskas A, Prosser JI, Nicol GW (2011) Cultivation of an obligate acidophilic ammonia oxidizer from a nitrifying acid soil. Proc Natl Acad Sci USA 108:1589215897

Leininger S, Urich T, Schloter M, Schwark L, Qi J, Nicol GW, Prosser JI, Schuster SC, Schleper C (2006) Archaea predominate among ammonia-oxidizing prokaryotes in soils. Nature 442:806-809

Linder S (1995) Foliar analysis for detecting and correcting nutrient imbalances in Norway spruce. Ecol Bull 44:178-190

MacDonald NW, Zak DR, Pregitzer KS (1995) Temperature effects on kinetics of microbial respiration and net nitrogen and sulfur mineralization. Soil Sci Socf Am J 59:233-240

Melillo JM, Steudler PA, Aber JD, Newkirk K, Lux H, Bowles FP, Catricala C, Magill A, Ahrens T, Morrisseau S (2002) Soil warming and carbon-cycle feedbacks to the climate system. Science 298:2173

Montealegre CM, Van Kessel C, Blumenthal JM, Hur HG, Hartwig UA, Sadowsky MJ (2000) Elevated atmospheric $\mathrm{CO}_{2}$ alters microbial population structure in a pasture ecosystem. Glob Chang Biol 6:475-482

Nicol GW, Glover LA, Prosser JI (2003) The impact of grassland management on archaeal community structure in upland pasture rhizosphere soil. Environ Microbiol 5:152-162 
Nicol GW, Tscherko D, Embley TM, Prosser JI (2005) Primary succession of soil Crenarchaeota across a receding glacier foreland. Environ Microbiol 7:337-347

Nicol GW, Tscherko D, Chang L, Hammesfahr U, Prosser JI (2006) Crenarchaeal community assembly and microdiversity in developing soils at two sites associated with deglaciation. Environ Microbiol 8:1382-1393

Nicol GW, Leininger S, Schleper C, Prosser JI (2008) The influence of soil $\mathrm{pH}$ on the diversity, abundance and transcriptional activity of ammonia oxidizing archaea and bacteria. Environ Microbiol 10:2966-2978

Nugroho RA, Roling WFM, Laverman AM, Zoomer HR, Verhoef HA (2005) Presence of Nitrosospira cluster 2 bacteria corresponds to $\mathrm{N}$ transformation rates in nine acid Scots pine forest soils. FEMS Microbiol Ecol 53:473-481

Phillips CJ, Harris D, Dollhopf SL, Gross KL, Prosser JI, Paul EA (2000) Effects of agronomic treatments on structure and function of ammoniaoxidizing communities. Appl Environ Microb 66:5410-5418

Priha O, Smolander A (1999) Nitrogen transformations in soil under Pinus sylvestris, Picea abies and Betula pendula at two forest sites. Soil Biol Biochem 31:965-977

Rasche F, Knapp D, Kaiser C, Koranda M, Kitzler B, ZechmeisterBoltenstern S, Richter A, Sessitsch A (2011) Seasonality and resource availability control bacterial and archaeal communities in soils of a temperate beech forest. ISME J 5:389-402

Shen JP, Zhang LM, Guo JF, Ray JL, He JZ (2010) Impact of longterm fertilization practices on the abundance and composition of soil bacterial communities in Northeast China. Appl Soil Ecol 46:119-124

Slaney M, Wallin G, Medhurst J, Linder S (2007) Impact of elevated $\left[\mathrm{CO}_{2}\right]$ and temperature on bud burst and shoot growth of boreal Norway spruce. Tree Physiol 27:301-312

Stewart RB, Wheaton E, Spittlehouse DL (1998) Climate change: implications for the Boreal forest. In: Calgary $\mathrm{AB}$, Legge $\mathrm{AH}$, Jones LL (eds) Emerging air issues for the 21st century: the need for multidisciplinary management, Proceedings of a Speciality Conference, Sep. 22-24, 1997. Air and Waste Management Assoc, Pittsburg, pp 86-101

Strömgren M, Linder S (2002) Effects of nutrition and soil warming on stemwood production in a boreal Norway spruce stand. Glob Chang Biol 8:1194-1204

Sun Y, Xing W, Li J, Lu Y, Zuo J (2009) Microbial community in granules from a high-rate EGSB reactor. Appl Biochem Microbiol 45:593-598
Szukics U, Abell GCJ, Hödl V, Mitter B, Sessitsch A, Hackl E, Zechmeister Boltenstern S (2010) Nitrifiers and denitrifiers respond rapidly to changed moisture and increasing temperature in a pristine forest soil. FEMS Microbiol Ecol 72:395-406

Thompson JD, Higgins DG, Gibson TJ (1994) CLUSTAL W: improving the sensitivity of progressive multiple sequence alignment through sequence weighting, position-specific gap penalties and weight matrix choice. Nucleic Acids Res 22:4673-4680

Tourna M, Freitag TE, Nicol GW, Prosser JI (2008) Growth, activity and temperature responses of ammonia-oxidizing archaea and bacteria in soil microcosms. Environ Microbiol 10:1357-1364

Tourna M, Stieglmeier M, Spang A, Könneke M, Schintlmeister A, Urich T, Engel M, Schloter M, Wagner M, Richter A (2011) Nitrososphaera viennensis, an ammonia oxidizing archaeon from soil. Proc Natl Acad Sci USA 108:8420-8425

Urakawa H, Tajima Y, Numata Y, Tsuneda S (2008) Low temperature decreases the phylogenetic diversity of ammonia-oxidizing archaea and bacteria in aquarium biofiltration systems. Appl Environ Microb 74:894-900

Wallenstein MD, McNulty S, Fernandez IJ, Boggs J, Schlesinger WH (2006) Nitrogen fertilization decreases forest soil fungal and bacterial biomass in three long-term experiments. For Ecol Manag 222:459-468

Webster G, Embley TM, Prosser JI (2002) Grassland management regimens reduce small-scale heterogeneity and species diversity of $\{$ beta $\}$-proteobacterial ammonia oxidizer populations. Appl Environ Microbiol 68:20-30

Xu ZH, Chen CR, He JZ, Liu JX (2009) Trends and challenges in soil research 2009: linking global climate change to local long-term forest productivity. J Soils Sediments 9:83-88

Yergeau E, Bokhorst S, Kang S, Zhou J, Greer CW, Aerts R, Kowalchuk GA (2011) Shifts in soil microorganisms in response to warming are consistent across a range of Antarctic environments. ISME J 6 (3):692-702

Zhang LM, Wang M, Prosser JI, Zheng YM, He JZ (2009) Altitude ammonia-oxidizing bacteria and archaea in soils of Mount Everest. FEMS Microbiol Ecol 70:208-217

Zhang LM, Offre PR, He JZ, Verhamme DT, Nicol GW, Prosser JI (2010) Autotrophic ammonia oxidation by soil thaumarchaea. Proc Natl Acad Sci USA 107:17240-17245

Zogg GP, Zak DR, Ringelberg DB, MacDonald NW, Pregitzer KS, White DC (1997) Compositional and functional shifts in microbial communities due to soil warming. Soil Sci Soc Am J 61:475481 